\title{
Front Matter: Volume 8911
}

, "Front Matter: Volume 8911," Proc. SPIE 8911, International Symposium on Photoelectronic Detection and Imaging 2013: Micro/Nano Optical Imaging Technologies and Applications, 891101 (30 August 2013); doi: 10.1117/12.2044058

SDIE Event: ISPDI 2013 - Fifth International Symposium on Photoelectronic SPE. Detection and Imaging, 2013, Beijing, China 


\title{
International Symposium on Photoelectronic Detection and Imaging 2013
}

\section{Micro/Nano Optical Imaging Technologies and Applications}

\author{
Min Gu \\ Xiaocong Yuan \\ Min Qiu \\ Editors
}

25-27 June 2013

Beijing, China

\section{Organized by}

Photoelectronic Technology Committee, Chinese Society of Astronautics • Tianjin Jinhang Institute of Technical Physics (China) - Science and Technology on Low Light Level Night Vision Laboratory (China) - Science and Technology on Optical Radiation Laboratory (China) - Science and Technology on Electromagnetic Scattering Laboratory (China)

Sponsored by

SPIE • The Optical Society • European Optical Society • Chinese Society of Astronautics

Published by

SPIE

Volume 8911 
The papers included in this volume were part of the technical conference cited on the cover and title page. Papers were selected and subject to review by the editors and conference program committee. Some conference presentations may not be available for publication. The papers published in these proceedings reflect the work and thoughts of the authors and are published herein as submitted. The publisher is not responsible for the validity of the information or for any outcomes resulting from reliance thereon.

Please use the following format to cite material from this book:

Author(s), "Title of Paper," in International Symposium on Photoelectronic Detection and Imaging 2013: Micro/Nano Optical Imaging Technologies and Applications, edited by Min Gu, Xiaocong Yuan, Min Qiu, Proceedings of SPIE Vol. 8911 (SPIE, Bellingham, WA, 2013) Article CID Number.

ISSN: 0277-786X

ISBN: 9780819497802

Published by

SPIE

P.O. Box 10, Bellingham, Washington 98227-0010 USA

Telephone +1 3606763290 (Pacific Time) · Fax +1 3606471445

SPIE.org

Copyright (C) 2013, Society of Photo-Optical Instrumentation Engineers.

Copying of material in this book for internal or personal use, or for the internal or personal use of specific clients, beyond the fair use provisions granted by the U.S. Copyright Law is authorized by SPIE subject to payment of copying fees. The Transactional Reporting Service base fee for this volume is $\$ 18.00$ per article (or portion thereof), which should be paid directly to the Copyright Clearance Center (CCC), 222 Rosewood Drive, Danvers, MA 01923. Payment may also be made electronically through CCC Online at copyright.com. Other copying for republication, resale, advertising or promotion, or any form of systematic or multiple reproduction of any material in this book is prohibited except with permission in writing from the publisher. The CCC fee code is 0277-786X/13/\$18.00.

Printed in the United States of America.

Publication of record for individual papers is online in the SPIE Digital Library.

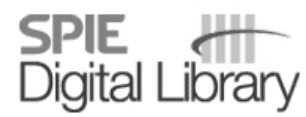

SPIEDigitalLibrary.org

Paper Numbering: Proceedings of SPIE follow an e-First publication model, with papers published first online and then in print and on CD-ROM. Papers are published as they are submitted and meet publication criteria. A unique, consistent, permanent citation identifier (CID) number is assigned to each article at the time of the first publication. Utilization of CIDs allows articles to be fully citable as soon as they are published online, and connects the same identifier to all online, print, and electronic versions of the publication. SPIE uses a six-digit CID article numbering system in which:

- The first four digits correspond to the SPIE volume number.

- The last two digits indicate publication order within the volume using a Base 36 numbering

system employing both numerals and letters. These two-number sets start with 00, 01, 02, 03, 04, $05,06,07,08,09,0 A, 0 B \ldots 0 Z$, followed by 10-1Z, 20-2Z, etc.

The CID Number appears on each page of the manuscript. The complete citation is used on the first page, and an abbreviated version on subsequent pages. Numbers in the index correspond to the last two digits of the six-digit CID Number. 


\title{
Contents
}

\author{
vii Conference Committee \\ ix Introduction
}

\section{MICRO/NANO OPTICAL IMAGING TECHNOLOGIES AND APPLICATIONS}

891104 Inline contaminants detection with optical microfiber in high-power laser system [8911-4] Z. Wei, Z. Song, Y. Yu, X. Zhang, Z. Meng, National Univ. of Defense Technology (China)

891105 Design and simulation of double annular illumination mode for microlithography [891 1-5] Q. Song, Shanghai Institute of Optics and Fine Mechanics (China) and Univ. of the Chinese Academy of Sciences (China); J. Zhu, Shanghai Institute of Optics and Fine Mechanics (China); B. Yang, L. Liu, J. Wang, H. Huang, Shanghai Institute of Optics and Fine Mechanics (China) and Univ. of the Chinese Academy of Sciences (China)

891106 Design and fabrication of filtering artificial-compound-eye and its application in multispectral imaging [8911-9]

J. Jin, S. Di, Guangzhou Institutes of Advanced Technology (China); Y. Yao, The Chinese Univ. of Hong Kong (China); R. Du, Guangzhou Institutes of Advanced Technology (China) and The Chinese Univ. of Hong Kong (China)

891107 Exploiting adaptive total variation model for image reconstruction from speckle patterns [8911-10]

C. Gong, X. Shao, T. Wu, Xidian Univ. (China)

891108 Preparation and characterization of A-site doped Perovskite-type manganese oxides [8911-12]

Y. Huang, X. Li, X. Che, H. Ju, Beijing Technology and Business Univ. (China)

891109 Screw thread parameter measurement system based on image processing method [8911-16]

Z. Rao, K. Huang, J. Mao, Y. Zhang, F. Zhang, Beifang Univ. of Nationalities (China)

$89110 \mathrm{~A}$ Integrated microfluidic spectroscopic sensor using arrayed waveguide grating [8911-17] Z. Hu, National Institute of Metrology (China); A. Glidle, C. N. Ironside, M. Sorel, M. Strain, J. M. Cooper, H. Yin, Univ. of Glasgow (United Kingdom)

8911 OB A review of developments in the preparation methods of tantalum pentoxide film [8911-18] S. Hu, R. Peng, Y. Li, J. Chen, Univ. of Shanghai for Science and Technology (China)

$89110 \mathrm{C} \quad$ Flat dielectric grating focusing lens with TE-polarized incident light [8911-19] T. Ma, X. Yuan, W. Ye, W. Xu, National Univ. of Defense Technology (China)

8911 OD High speed optical nanoscopy by stimulated emission depletion (STED) with galvo mirrors [8911-20]

S. Li, C. Kuang, Y. Wang, X. Hao, P. Xiu, Y. Xu, X. Liu, Zhejiang Univ. (China) 
8911 OE Transient $x$-ray diffraction to measure the dynamic response of shocked lithium fluoride single crystal [8911-21]

H. Wang, Chongqing Univ. (China) and China Academy of Engineering Physics (China);

Y. Ye, Q. Yang, M. Li, China Academy of Engineering Physics (China); S. Xiao, Chongaing Univ. (China); Z. Li, China Academy of Engineering Physics (China)

$89110 \mathrm{~A}$ An algorithm for restoring the wafer surface based on B-spline surface reconstruction [8911-24]

N. Wang, Institute of Optics and Electronics (China) and Graduate Univ. of Chinese Academy of Sciences (China); W. Jiang, Institute of Optics and Electronics (China) and Sichuan Univ. (China); W. Yan, S. Hu, Institute of Optics and Electronics (China)

$8911 \mathrm{OH} \quad$ Nano-scale memristor SPICE implementation using ideal operational amplifier model [8911-25]

K. XU, Univ. of Electronic Science and Technology of China (China) and Duke Univ. (United States); Y. Zhang, Univ. of Electronic Science and Technology of China (China); L. Wang, Duke Univ. (United States); M. Yuan, Wave Computation Technologies, Inc. (United States); W. T. Joines, Q. H. Liu, Duke Univ. (United States)

89110 A research of a high precision multichannel data acquisition system [8911-27] L. Zhong, Institute of Optics and Electronics (China) and Univ. Of the Chinese Academy of Sciences (China); X. Tang, W. Yan, Institute of Optics and Electronics (China)

$89110 \mathrm{~J} V e c t o r$ analysis of two-dimensional Ronchi grating in the metrology system [8911-28] Z. Yao, Institute of Optics and Electronics (China) and Univ. of the Chinese Academy of Sciences (China); T. Xing, Institute of Optics and Electronics (China)

8911 OK Research on generating various polarization-modes in polarized illumination system [8911-33]

J. Huang, Institute of Optics and Electronics (China) and Univ. of the Chinese Academy of Sciences (China); W. Lin, Z. Fan, Institute of Optics and Electronics (China)

$8911 \mathrm{OL} \quad$ Broadband infrared absorber based on plasmonic hybrid resonator [8911-35] Q. Liang, D. Hao, T. Wang, Z. Lu, Q. Sun, W. Yu, Changchun Institute of Optics, Fine Mechanics and Physics (China)

$89110 \mathrm{M}$ Study of the impact of gas temperature and pressure on image quality of lithography objective lens [8911-39]

C. Zhou, Institute of Optics and Electronics (China) and Univ. of the Chinese Academy of Sciences (China); T. Xing, Institute of Optics and Electronics (China)

$89110 \mathrm{~N}$ Design of an optical system with large depth of field using in the micro-assembly [8911-40] R. Li, J. Chang, Z. Zhang, X. Ye, H. Zheng, Beijing Institute of Technology (China)

$891100 \quad$ Effect of fabrication errors on binary optical element imaging quality [8911-41]

S. Wang, Institute of Optics and Electronics (China) and Univ. of the Chinese Academy of Sciences (China); W. Yang, S. Wu, Institute of Optics and Electronics (China) 
$89110 Q$ Orthogonal experiment and analysis on process parameters of bowl feed polishing (BFP) [891 1-43]

K. Meng, Institute of Optics and Electronics (China) and Univ. of the Chinese Academy of Sciences (China); Y. Wan, Q. Xu, Institute of Optics and Electronics (China); Y. Zhang,

Sichuan Univ. (China)

8911 OR Illumination optimization in optical projective lithography [8911-46]

$H$. Jiang, Institute of Optics and Electronics (China) and Graduate School of the Chinese Academy of Sciences (China); T. Xing, Institute of Optics and Electronics (China); M. Du, A. Chen, Institute of Optics and Electronics (China) and Graduate School of the Chinese Academy of Sciences (China)

8911 OS Simulation and representation turbulent wavefront according to transformation Gaussian lasers into patterned light fields by diffractive micro-optics elements [8911-47] Y. Qu, X. Zhang, H. Sang, C. Xie, Huazhong Univ. of Science and Technology (China)

8911 OT The focal spot shape and point spread function of liquid crystal microlens with different pattern electrodes [8911-49]

S. Kang, Huazhong Univ. of Science and Technology (China) and Wuhan Polytechnic Univ. (China); X. Zhang, H. Sang, C. Xie, Huazhong Univ. of Science and Technology (China)

$89110 \mathrm{U}$ Cross-correlation analysis for live-cell image trajectory [8911-50]

C.-M. Cheng, Industrial Technology Research Institute (Taiwan, China); Y.-F. Chang, Tao Shin Hospital (Taiwan, China); C. Wu, National Tsing Hua Univ. (Taiwan, China)

8911 OV Error analysis for aspheric surface testing system [8911-54]

J. Feng, Institute of Optics and Electronics (China) and Univ. of the Chinese Academy of Sciences (China); C. Deng, T. Xing, Institute of Optics and Electronics (China)

$89110 \mathrm{X}$ Iterative learning control for synchronization of reticle stage and wafer stage in step-and-scan lithographic equipment [8911-59]

L. Li, Institute of Optics and Electronics (China) and Univ. of the Chinese Academy of Sciences (China); S. Hu, L. Zhao, P. Ma, Institute of Optics and Electronics (China)

8911 OY Modeling and simulation of nematic liquid crystal microlens with electrically focal-swing over focal plane [8911-60]

Z. Mei, S. Kang, X. Zhang, H. Sang, C. Xie, Huazhong Univ. of Science and Technology (China)

$89110 Z$ Comparative study of wavefront coding imaging with rotational and non-rotational symmetric phase masks [8911-63]

J. Hu, F. Xu, X. Zhao, C. Wang, Soochow Univ. (China)

891110 Absorption enhancement of In0.53 Ga0.47As photodetector with rear plasmonic nanostructure [8911-64]

B. Xu, J. Liu, W. Wang, Y. Xu, Q. Wang, G. Song, X. Wei, Institute of Semiconductors (China)

891111 Optical surface measurement using phase retrieval hybrid algorithm based on diffraction angular spectrum theory [8911-67]

L. Feng, Institute of Optics and Electronics (China) and Univ. of the Chinese Academy of Sciences (China); Z. Zeng, Y. Wu, Institute of Optics and Electronics (China) 
891112 Infrared stop-band filter based on a subwavelength structure [8911-68]

Y. Song, C. Wang, Y. Lou, B. Cao, X. Li, Soochow Univ. (China)

Author Index

Proc. of SPIE Vol. $8911891101-6$

Downloaded From: https://www.spiedigitallibrary.org/conference-proceedings-of-spie on 26 Apr 2023 Terms of Use: https://www.spiedigitallibrary.org/terms-of-use 


\title{
Conference Committee
}

\author{
Conference Chairs
}

Konstantin Vodopyanov, Stanford University (United States) and CREOL, The College of Optics and Photonics, University of Central Florida (United States)

Guofan Jin, Tsinghua University (China)

Songlin Zhuang, University of Shanghai for Science and Technology (China)

Local Organizing Committee

Jiaqi Wang, Changchun Institute of Optics, Fine Mechanics and Physics (China)

Zuyan Xu, Technical Institute of Physics and Chemistry (China)

Zunqi Lin, Shanghai Institute of Optics and Fine Mechanics (China)

Dianyuan Fan, Shanghai Institute of Optics and Fine Mechanics (China)

Jingshan Jiang, Center for Space Science and Applied Research (China)

Liwei Zhou, Beijing Institute of Technology (China)

Shouhuan Zhou, North China Research Institute of Electro-optics (China)

Desheng Jiang, Wuhan University of Technology (China)

Jianquan Yao, Tianjin University (China)

Qingxi Tong, Institute of Remote Sensing and Digital Earth (China)

Junhao Chu, Shanghai Institute of Technical Physics (China)

Yongqi Xue, Shanghai Institute of Technical Physics (China)

Program Committee

Junhao Chu, Chair, Shanghai Institute of Technical Physics (China)

Jinxue Wang, Chair, Raytheon Company (United States)

Min Gu, Swinburne University of Technology (Australia)

Andreas Tünnermann, Friedrich-Schiller-Universität Jena (Germany)

Connie Chang, University of California, Berkeley (United States)

Shibin Jiang, AdValue Photonics Inc. (United States)

H. C. Liu, Shanghai Jiao Tong University (China)

Xiaocong Yuan, Nankai University (China)

Wei Shi, Tianjin University (China)

Min Qiu, Zhejiang University (China)

Nanjian Wu, Institute of Semiconductors (China)

Session Chairs

Micro/Nano Optical Imaging Technologies and Applications

Min Gu, Swinburne University of Technology (Australia)

Xiaocong Yuan, Nankai University (China)

Min Qiu, Zhejiang University (China) 


\section{Introduction}

We have had the great honor of organizing the Fifth International Symposium on Photoelectronic Detection and Imaging (ISPDI) in Beijing. It was truly a great pleasure for us to greet the more than 1,200 participants from many different countries attending ISPDI 2013! I firmly believe that the symposium will become an important international event in the field of photoelectronic detection and imaging technology.

ISPDI 2013 was sponsored by SPIE, The Optical Society, European Optical Society, and the Chinese Society of Astronautics, and was organized by the Photoelectronic Technology Committee, Chinese Society of Astronautics, Tianjin Jinhang Institute of Technical Physics, Science and Technology on Low Light Level Night Vision Laboratory, Science and Technology on Optical Radiation Lab. and Science and Technology on Electromagnetic Scattering Lab. There were 26 cooperating organizations that supported the meeting. Nearly 850 papers were accepted for presentation at ISPDI 2013, contributed by over 1,370 authors from more than 10 countries, including the United States, United Kingdom, Germany, France, Norway, Australia, Canada, Japan, Korea, Russia, China, and so on. We had seven plenary speeches and 135 famous scientists and experts from home and abroad to present the invited talks at 10 different conferences.

The purpose of ISPDI 2013 is to provide a forum for the participants to report and review the innovative ideas and up-to-date progress and developments, and discuss the novel approaches to applications in the field of photoelectronic detection and imaging. It is sincerely hoped that the research and developments in optical and photoelectronic fields will be promoted, and that international cooperation and the sharing of common interests will be enhanced.

On behalf of Prof. Konstantin Vodopyanov, and the other conference chairs, and the Organization Committee of ISPDI, I would like to heartily thank our sponsors and cooperating organizations for all they have done for the meeting. Thanks also to all the authors for their contributions to the proceedings, to all of the participants and friends for their interest and efforts in helping us make the symposium possible, to the Program Committee for their effective work and valuable advice, and especially the ISPDI 2013 Secretariat and the SPIE staff for their tireless effort and outstanding service in preparing the meeting and publishing the conference proceedings.

Guofan Jin 